DOI:

\title{
TYPES AND FORMS OF CONTROL WHEN TEACHING RUSSIAN TO FOREIGN STUDENTS IN GROUPS WITH ENGLISH AS THE LANGUAGE OF INSTRUCTION
}

\author{
Larisa Skrypnyk, \\ Senior Lecturer \\ Olga Tesalovskaya \\ Senior Lecturer \\ Nataliya Chernogorskaya \\ Senior Lecturer \\ Kharkiv national university of civil engineering and architecture \\ (Kharkiv, Ukraine ) \\ e-mail: scripnick.larisa@yandex.ua \\ olga.tesalovskaya@ukr.net \\ nchern2367@gmail.com
}

\begin{abstract}
The article is devoted to analysis of different forms of control of knowledge, skills and abilities in teaching Russian as a foreign language. Their choice is determined by the communicative approach to learning and corresponds to the variety of types of speech activity. Monitoring and accounting of knowledge, skills and abilities is a necessary condition of the educational process. The effectiveness of the organization and monitoring largely depends on the success of work in a particular group of students. In communication oriented learning, control usually performs two basic functions-controlling and training. By exercising proper control, the teacher identifies gaps in students ' learning of educational material or the fact that certain skills are not formed, then works to eliminate these shortcomings by varying the learning strategy. The example developed examinations, the authors demonstrate the possibility of solving linguistic and linguodidactic tasks.
\end{abstract}

Keywords: the principle of communication orientation, knowledge control, current, intermediate and final control, subjective control, objective control, evaluation criteria

\section{ВИДЫ И ФОРМЫ КОНТРОЛЯ ПРИ ОБУЧЕНИИ ИНОСТРАННЫХ УЧАЩИХСЯ РУССКОМУ ЯЗЫКУ В ГРУППАХ С АНГЛИЙСКИМ ЯЗЫКОМ ОБУЧЕНИЯ}

\author{
Л. В. Скрипник \\ Старший преподаватель \\ О. Б. Тесаловская \\ Старший преподаватель \\ Н. Г. Черногорская \\ Старший преподаватель \\ Харьковский национальный университет строительства и архитектуры \\ (Харьков, Украина) \\ e-mail: scripnick.larisa@yandex.ua \\ olga.tesalovskaya@ukr.net \\ nchern2367@gmail.com
}


Аннотация. Статья посвящена анализу различных форм контроля знаний, умений и навыков при обучении русскому языку как иностранному. Их выбор обусловлен коммуникативным подходом к обучению и соответствует многообразию видов речевой деятельности. Контроль и учет знаний, умений и навыков является необходимым условием учебного процесса. От эффективности организации и проведения контроля во многом зависит успешность работы в конкретной группе учащихся. При коммуникативно ориентированном обучении контроль обычно выполняет две базовые функции - контролирующую и обучающую. Осуществляя собственно контроль, преподаватель выявляет пробелы в усвоении учащимися учебного материала или факта несформированности тех или иных умений, затем проводит работу по устранению этих недостатков посредством варьирования стратегии обучения. На примере разработанных контрольных работ авторы наглядно показывают возможность решения лингвометодических и лингводидактических задач.

Ключевые слова: принцип коммуникативной направленности, контроль знаний, текущий, промежуточный и итоговый контроль, субъективный контроль, объективный контроль, критерии оценки.

\section{INTRODUCTION}

Globalization of the entire world space leads to the fact that Ukrainian education (as an economy and politics) needs to adapt to the requirements of the world community. Therefore, many universities in Ukraine teach in English, as this gives students the opportunity to get acquainted with the most modern theories, hypotheses and innovations that are not yet developed in Ukraine. Modern students understand that access to up-to-date information can help improve the quality and quantity of knowledge they receive.

Teaching students in groups with English as the language of education at the Department of Ukrainian language and language training of foreign citizens is subject to the principle of communication orientation, which is the leading one in modern methods. Foreign students of our University are trained in communication activities in various forms, and the construction of the learning system is determined by this. The principle of communicative orientation includes a number of linguomethodological requirements, this is a strict, linguistically justified minimum of language material, providing a level of communicative necessity and sufficiency; assessment of each speech product from the point of view of the reality of its appearance in natural acts of speech communication; building the subjects of the educational material in strict accordance with the social and communicative role of the future specialist; communicativeness of speech operations when working on linguistic material; creation by the work system of a motivated need for verbal communication, including in the language of the country where foreign students are trained.

The most important element of the communicative training methodology is the organization of an effective control system. Effective control allows not only to evaluate the activities of foreign students in the educational process, determine their level of proficiency in foreign language speech, establish a correspondence between the intended goal and the results achieved, but also to determine the degree of effectiveness of the basic training system and, if necessary, significantly modify it in the direction of improvement and optimization.

\section{LITERATURE REVIEW}

Monitoring and accounting of knowledge, skills and abilities is a necessary condition of the educational process. The effectiveness of the organization and monitoring largely depends on the success of work in a particular group of students. In communicatively oriented learning control usually performs two basic functions - controlling and teaching. Exercising control itself, the teacher identifies gaps in the assimilation of educational material by students or the fact that certain skills are not formed, then works to eliminate these shortcomings by varying the teaching strategy. No less important is the teaching function of control, which is expressed in the formation of self-control and self-assessment mechanisms in students as factors that guide and stimulate their educational, cognitive and communicative activities.

According to psychologists, the process of learning foreign languages, the process of educational, 
cognitive and communicative activities can be perfect only if the assessment does not complete, but accompanies it at all stages of language acquisition (Akishina, Kagan 2020: 164). Therefore, the control stages should correspond to the training stages. In this case, the control will be related to a specific stage in the formation of communicative competence.

A clear control system is of great importance at all stages of training. Usually in the methodology of teaching Russian as a foreign language when developing a control system, the following are distinguished: compliance of the control method with the given training conditions, its training character, its effectiveness and reliability, ease of evaluating the result, the real possibility of its application and cost-effectiveness of the control method (Borisova, Latysheva 2003-2004: 62).

In the methodological literature, control is understood not only to highlight some of the qualitative parameters of training, but also to establish its quantitative characteristics. In this case, control is not only a determination of the knowledge, skills and abilities acquired by students, but also material for making changes in the learning process.

The types and forms of control are determined by the general objectives of training. In the modern methodology of teaching Russian as a foreign language, three types of control are distinguished: current, intermediate and final. We use the same types of control in groups with English teaching.

\section{RESEARCH METHODS}

Current control can be carried out at each lesson. Its purpose is to test the level of maturity of specific skills among foreign students. The unit of check can be a word, phrase, part of a sentence, grammatical structure, sentence, cliché, etc. Usually, current control is carried out regularly as you go through a certain lexical and grammatical material. This can be control in the form of choosing the correct option from 3-4 sentences, transformation of the proposed samples, filling in gaps in sentences, etc. The forms and methods of current control are varied. As a rule, they depend on the type of lesson and the stage of training.

The purpose of the intermediate control is to check the degree of formation of certain skills and abilities in foreign students on a certain lexico-grammatical and speech material. Intermediate control can be carried out at the end of a cycle of classes related to each other by a single educational topic. This control

can be carried out in the form of a conversation between a teacher and students on previously given questions in order to find out their knowledge; discussion of speeches on a specific topic. It is also advisable to carry out control works. Tasks intended for intermediate control, by their nature, do not differ significantly from the tasks of current control, but cover a wider scope of material. The level of preparation of students in groups with English as the language of education is also important.

Final control is used to check the level of formation of a set of skills and abilities in all types of communication activities. This type of control is usually carried out at the end of the school year. The forms of communicative control can be very diverse.

Examples of final control tasks:

Задание 1. От данных глаголов образуйте отглагольные существительные. Проследите за изменением управления.

создавать портрет - ...; смешивать краски - ...; составлять палитру - ...; распределять детали ...; разрабатывать фон - ...; соединять элементы - ..; подготавливать холст - ...; расписывать холст - ...; осуществлять замысел - ... .

Задание 2. Составьте предложения, используя данные сведения и глаголь строить, сооружать, возводить в нужной форме.

1. Храм Зевса в Олимпии - 468 гг. до н.э. 2. Луксорский храм - ХV-ХІІІ в. до н.э. 3. Акрополь -V в. до н.э. 4. Колизей - 75-80 г2 до н.э. 5. Площадь Капитолия - $1594-1538$ г2 до н.э. 6. Десятинная иерковь в Киеве - 989-996 г2. 7. Софийский собор в Киеве - 1037-1054 г2.

These include: dialogues on specific topics; question-answer conversations; stories on specific topics; stories with visual support; retellings, etc. (oral speech); written answers to questions; presentations, 92 
compositions with visual support, etc. (written speech). In the modern method of teaching Russian as a foreign language, it is customary to distinguish two types of control: subjective control and objective control (Voronina 2017: 29).

Subjective control is mainly intended to test the receptive, reproductive and productive communication activities of trainees. The forms of subjective control are written tests and oral questioning. Written tests are carried out at the end of a cycle of classes on a specific topic. Oral questioning is commonly used in every lesson.

To control productive speech skills, the following criteria are usually taken as a basis: a) speech rate, the number of statements per unit of time; b) reaction time in spontaneous communication; c) the degree of combination of language and speech material; d) the use of ready-made forms, communication blocks, idioms, etc.; e) the degree of syntax complexity; f) the detail of the response, message; g) non-standard statement; h) the number of errors per unit of the statement (Yerchak 2013: 62).

Objective forms of control are used to check the level of students ' proficiency in a set of lexical and grammatical tools, as well as to check individual receptive skills. Tests are usually used as such. Tests are a form of standardized control. All test tasks have the same structure and are performed the same way. Instructions for their implementation are given once at the beginning of testing. In the process of completing the test task, students form a primary skill, i.e. the ability to perform mental operations while concentrating on them with arbitrary attention, and the automation of speech utterance is carried out in the classroom under the guidance of a teacher.

The test control is objective, giving information about the process of mastering each topic; complete in terms of coverage of both students in the study group and the main topics of the course being studied; natural in terms of the conditions in which students are located; short, quickly giving information about the results of control to students and the teacher. It focuses on the most important in the studied material information, allows you to immediately intervene in the learning process, gives information not only about outcomes but also about the course of thinking, carries educational start makes carefully analyze linguistic phenomena, developing observation skills, language guess. Test control helps the teacher to identify not only the "error zone" (Lyakhovitsky 1998: 119) of foreign students in the process of teaching Russian, but also the degree of ability to study independently.

Examples of test control:

Задание 1 Дополните предложения лексикой на основе множественного выбора.

1) Камень служит материалом для ...

2) Материалом для облицовки стен служит ...

3) Необходимым материалом в производстве

бетона является ...

4) Из кирпича строят ... а) потолок;

б) фундамент;

в) перегородка;

а) мрамор;

б) бетон;

в) стекло;

а) дерево;

б) мел;

в) гравий;

а) дома;

б) набережные; 
в) плотины;

5) Многоэтажные дома строят из ...

а) кирпич;

б) пластмасса;

в) бетон.

Oral speech is one of the most complex objects of control. This is explained by the fact that adequate control of oral speech requires not only an assessment of communicative competence, which includes various skills, but also an assessment of the product and process of speaking. However, in order to evaluate one or another product-text, it is required to simultaneously evaluate: the choice of linguistic means of various levels (phonetic-intonation, lexical, morphological, syntactic, stylistic), on which the correct construction of a speech work depends; its content and informational content; the form of presentation of the content, the degree of its organization, the logical and semantic structure, the degree of planning and understanding of the text, the degree of achievement of the communicative goal, etc. And to assess the quality of the speaking process, you need to take into account certain characteristics, the presence of self-control, and so on. Such a number of objects, of course, cannot be in the field of view of the teacher at the same time, because the possibilities of conscious human perception are limited. This creates a contradiction between the multiplicity of objects subject to control, on the one hand, and the $\mathrm{n}$ opinion, is the distribution of control objects by their levels.

\section{RESULTS AND DISCUSSION}

The triplicity of language phenomena and the psychological characteristics of speaking as a type of communicative activity requires the teacher to distinguish three basic levels at each stage of control in the field of speaking.

At the first level of control, we check the skills of operating with language aspects (phonetics, vocabulary, grammar) necessary for speech activity to take place at all. At the second level, formal indicators of the success of speech activity are checked, mainly related to the processality of speaking (all kinds of quantitative indicators: the time of speech reaction to the partner's remark; the rate of information growth; the presence and degree of self-control). Finally, at the third, the highest level of control, the teacher focuses on the intentional and semantic aspects of speech activity, embodied in the product of this activity - a speech work constructed by the student in accordance with the achieved step-by-step skills, as well as with the degree of development of his communicative competence.

In our opinion, the implementation of such multi-level control in the field of speaking will ensure the gradual coverage of all the necessary objects included in the field of speaking and will contribute to the successful control at the final stage when checking the ability of students to carry out speech activities in a foreign language. In addition, the organization of such monitoring will help to more accurately diagnose the causes that make it difficult to implement communication in the context of foreign-language activities. In addition, the main problem in organizing work and conducting control in groups with English as a language of education is the limited number of training hours for teaching Russian as a foreign language, which, in turn, makes it difficult to implement communication in the context of foreign-language activities.

\section{CONCLUSION}

In conclusion, we list the main methodological requirements that must be taken into account when building a reliable, efficient, cost-effective and effective control system in the educational process of Russian as a foreign language. These include: mandatory consideration of the linguistic thesaurus of students, which must be formed at a specific stage of training. Taking into account the main linguistic and psychological difficulties manifested in typical mistakes of the operational level. Taking into account the actual skills in which the skills acquired by students will function. Accounting for automation of General functional mechanisms, such as operational memory, anticipation, language and semantic guesswork, and operational meaning-forming mechanisms. Each level of control should correspond to its most economical and adequate 
forms of control, types and types of control tasks. For each stage, its own evaluation criteria should be developed.

\section{REFERECES}

Akishina, A.A., Kagan, O.E. (2020). Uchimsya uchit: Dlya prepodavateley russcogo yazyka kak inostrannogo.[Learning to Teach: For teachers of Russian as a foreign language] -2nd ed., corrected and additional - M.: Russian language. Courses.

Borisova, E. G., Latysheva, A. N. (2003-2004). Lingvistichesksye osnovy RKI (pedagodicheskaya grammatika russcogo yazyka) [Linguistic foundations of Russian language teaching (pedagogical grammar of the Russian language)]: Textbook. Moscow.

Voronina, L. A. (2017). Praktikum po texnoligiyam obucheniya inostrannym yazykam. [Workshop on technologies of teaching foreign languages] [Electronic resource]: educational and methodical manual / L. A. Voronina, G. A. Baeva; EBS Znanium. - Saint Petersburg: publishing house of the Saint Petersburg University, p. 29. - ISBN 978-5-288-05759-5. http://znanium.com/bookread2.php?book=999676.

Yerchak, N. T. (2013). Inostrannyye yazyki: psychologiya usvoyeniya. [Foreign languages: psychology of assimilation] [Electronic resource]: textbook /N. T. Yerchak; EBS Znanium. - Mn.:New knowledge: M.: NIZ INFRAM, p. 36. - ISBN 978-5-16-006557-1. : http://znanium.com/bookread2.php?book=397227.

Lyakhovitsky, M. V. (1998). Methodika prepodavaniya inostrannogo yazyka. [Methods of teaching a foreign language : textbook. manual]/ M. V. Lyakhovitsky. - M.: Higher school, p.140.

Shchukin, A. N. (2006). Obucheniya inostrannym yazykam. [Teaching of foreign languages].- M., p. 295.

Sarkar Archan (2019) Languages and intermediate language - polyfony as a method of teaching lexis and its research // International Scientific-Pedagogical Organization of Philologists “WEST-EAST ” (ISPOP). Scientific Journal "WEST-EAST". Vol. 212, N1 (October, 2019). pp. 119- 122. https://doi.org/10.33739/2587-5434-2019-2-2-119-122

\section{For citation:}

Larisa Skrypnyk, L. \& Olga Tesalovskaya, O. \& Chernogorskaya, N. (2020). Types and forms of control when teaching Russian to foreign students in groups with English as the language of instruction // International Scientific-Pedagogical Organization of Philologists "WEST-EAST" (ISPOP). Scientific Journal "WEST-EAST". Vol. 3, N1 (October, 2020). pp. 83-89. doi:

\section{Для цитирования:}

Скрипник, Л. В., Тесаловская, О. Б., Черногорская, Н. Г. (2020) Виды и формы контроля при обучении иностранных учащихся русскому языку в группах с английским языком обучения // International Scientific-Pedagogical Organization of Philologists "WEST-EAST" (ISPOP). Scientific Journal "WEST-EAST". Vol.3, N1 (October, 2020). c. 83-89. doi:

\section{Information about the authors:}

Skrypnyk Larisa - Senior lecturer of the Department of Ukrainian Language and Language Training of Foreign Citizens, Kharkov National University of Construction and Architecture, Kharkov, Ukraine. e-mail: scripnick.larisa@yandex.ua

Tesalovskaya Olga - Senior lecturer of the Department of Ukrainian Language and Language Training of Foreign Citizens, Kharkov National University of Construction and Architecture, Kharkov, Ukraine. e-mail:olga.tesalovskaya@ukr.net 
Chernogorskaya Nataliya - Senior lecturer of the Department of Ukrainian Language and Language Training of Foreign Citizens, Kharkov National University of Construction and Architecture, Kharkov, Ukraine.

e-mail: nchern2367@gmail.com

\section{Сведения об авторе:}

Скрипник Лариса Викторовна - старший преподаватель кафедры украинского языка и языковой подготовки иностранных граждан, Харьковский национальный университет строительства и архитектуры, Харьков, Украина.

e-mail: scripnick.larisa@yandex.ua

Тесаловская Ольга Борисовна - старший преподаватель кафедры украинского языка и языковой подготовки иностранных граждан, Харьковский национальный университет строительства и архитектуры, Харьков, Украина.

e-mail: olga.tesalovskaya@ukr.net

Черногорская Наталья Георгиевна - старший преподаватель кафедры украинского языка и языковой подготовки иностранных граждан, Харьковский национальный университет строительства и архитектуры, Харьков, Украина.

e-mail: nchern2367@gmail.com

Manuscript received: 13/08/2020

Accepted for publication: $14 / 09 / 2020$

Рукопись получена: 13/08/2020

Принята к печати: 14/09/2020 